\title{
The Evolution of Forming "Territories of Traditional Nature Use" in the Sakha Republic (Iakutiia)
}

\author{
NICHOLAS PARLATO, GAIL FONDAHL, \\ VIKTORIYA FILIPPOVA, AND ANTONINA SAVVINOVA
}

\begin{abstract}
In the struggle of Russia's Indigenous northerners for greater control over their ancestral lands, the spatiolegal formations known as Territories of Traditional Nature Use (TTPs, using the Russian acronym) have become their most effective tool. TTPs have assumed diverse characteristics across Russian regions in response to the evolution of federal and sub-federal law and of center-periphery relations at national and regional scales. In the Sakha Republic (Iakutiia), TTP formation is entangled with wider territorial politics and economic trends, which have led to the precarious but powerful advancement of Indigenous rights. This article explores this evolution by comparing the creation of two neighboring TTPs, formed eight years apart under distinct political and legislative conditions. A combination of local efforts, subnational legislative and economic initiatives, and reaction to federal overstep have compelled the improvement and systematization of Indigenous rights in the republic.
\end{abstract}

Keywords: center-periphery, Indigenous rights, land use, local empowerment, Sakha Republic (Iakutiia)

$\mathrm{R}^{\mathrm{s}}$ ussia's Indigenous northerners' attempts to protect their ancestral lands for the pursuit of traditional activities, especially from extractive industries, is well documented (Balzer 2006, 2016; Fondahl and Poelzer 2003; Shadrin 2014; Sirina 2010; Stammler and Ivanova $2016 \mathrm{a} \& \mathrm{~b}) .^{1}$ In this struggle, the spatiolegal formations known as Territories of Traditional Nature Use (TTPs) have proven the most effective tool in asserting their constitutional and federally secured rights (Potravniy et al. 2017). Since 2001, more than five hundred TTPs 
have been established across the Russian North. The rationales, timing, and procedures for doing so have changed with the modifications to federal and sub-federal legislation and with continually shifting centerperiphery relations. Although TTPs can be seen as an expansion of state discipline and reproduction of power relations that subordinates Indigenous rights to state discretion, they are also an assertion of local interests and identities through legal actions and channels. In a close examination of the creation of two neighboring TTPs within the Sakha Republic (Iakutiia), one of the Russian Federation's 80-plus “federal subjects" (regions), we explore the evolving role TTPs have played in both local (Indigenous) struggles to protect ancestral lands and in regional struggles against the centralization of federal power.

\section{What Is a TTP? Legal Definition}

A 1992 edict (No. 397) from President Boris Yeltsin called for the protection of Indigenous northerners' ancestral territories. ${ }^{2}$ To address this demand, in 2001 federal legislators laid out the basic framework for establishing TTPs in Russia via a federal law "On Territories of Traditional Nature Use" (RF 2001a). The law defines TTPs as "specially protected nature territories, formed for the purposes of traditional natural resource use and traditional way of life of the Indigenous numerically small peoples of the North, Siberia and the Far East of the Russian Federation" (RF 2001a, Article 1). It stipulates that a further goal of the TTP is to preserve biodiversity (Article 4). Once created, a TTP endows Indigenous northerners with the right to hunt and fish without a license and to collect and control information about their territory (e.g., number of animals, sites of hunting cabins, numbers of hunters and fishermen, locations of industrial activity). Although the law on TTPs does not preclude the "removal of land parcels or other isolated resources" from a TTP "for state or municipal needs" (Article 13), it enables Indigenous northerners to initiate dialogue with non-Indigenous resource users (extractive industries) over issues of ecological damage, compensation, partnership, assistance, and so on.

According to the federal law, TTPs can be of local, regional, or federal significance. The federal law on TTPs is often characterized as a "framework" law, or more critically, as a "declarative" law, providing only minimal detail on the concrete rules and procedures (nuts and bolts) for establishing and maintaining TTPs. ${ }^{3}$ Such "nuts and bolts" are usually provided by subsequent decrees (postanovleniia) and orders 
(rasporiazheniia), which have not been established in the federal legislature. A TTP of federal significance has yet to be established (Zadorin et al. 2017). Moreover, legislative interventions have over time compounded weaknesses in the federal TTP law by redacting articles, narrowing terminology, and enacting contradictory laws (Kondrashev et al. 2018; Minchenko 2007). The federal TTP law has undergone revision six times since its adoption in 2001. Other laws have further modified the TTP's force; most notably, in 2013, changes in the federal Land Codex resulted in the removal of TTPs from the list of "Specially Protected Nature Territories" (osobo okhraniaemaia prirodnaia territoriia [OOPT]).

\section{TTPs: Originally a Type of Specially Protected Nature Territory}

OOPTs include various types: nature reserves (zapovedniki), wildlife sanctuaries (zakazniki), national parks, nature parks (prirodnye parki), natural monuments, and others. The preamble to the 1995 federal law "On Specially Protected Nature Territories" defines them as: "parcels of land, the aquatic and atmospheric areas around and above them, where natural complexes and objects are located, which have special conservation, scientific, cultural, aesthetic, recreational, and health-related value, which are parceled off either entirely or partially by a decree of government organs from other forms of land use, and for which is established a special regime of protection" (RF 1995). These stipulations were echoed in Article 95 of the 2001 Land Codex (RF 2001b), prior to the 2013 amendments.

According to the legal scholar Alexander Tranin, the OOPT category of land is primarily intended to "protect biodiversity and support the balance of natural processes in the biosphere" (Tranin 2010, 70). Each type of OOPT has a distinct conservation objective, and the type of OOPT determines at which jurisdictional level it can be created. For instance, the establishment of a nature reserve (the most highly protected OOPT) requires federal approval, whereas OOPTs with less strict protection regimes, such as wildlife sanctuaries and nature parks, can be formed at a regional or local level.

TTPs, as a form of OOPT (until 2013), applied the general nature conservation principles of OOPTs, while incorporating the protection of Indigenous interests and rights to maintain their traditional way of life (Bogoslovskaya 2016; Naprasnikov et al. 2005; Tranin 2010). However, many of the specific processes of development, zoning, and implementation that were legislated for other OOPTs, including restrictions on 
vehicles and on construction with the boundaries of an OOPT, were not legally affirmed for TTPs at the federal level (Naprasnikov et al. 2005). OOPT status provided the TTP with a high level of protection in theory, although in practice such protection was vaguely defined and vulnerable to frequent violations (Tranin 2010).

\section{The Study Area and Methods}

In order to understand the evolving roles of TTPs in both the protection of Indigenous land and the assertion of regional autonomy, this article examines the formation of two TTPs within one district of the southern Sakha Republic (SR). SR long has held a frontline position for defending the rights of Indigenous northerners (Fondahl et al. 2000; Ivanova and Stammler 2017); it is also renowned for persistently asserting a considerable level of sovereignty in the face of federal centralization policies (Balzer 2016). The Bellet Evenk National Nasleg (BENN) (population 1,738, predominantly Evenki) covers 25,192 square kilometers of the western side of the Aldan District; the Anamy National Nasleg (ANN) (population 530, Evenk and Sakha) covers 67,275 square kilometers of its eastern side (figure 1). We chose to investigate the formation of these two neighboring TTPs, occupied by members of the same Indigenous cultural group (Evenki), because the ease, duration, and effects of the formation process depended greatly on their different geographies and on the political conditions prevailing at the moment at which each TTP was formed. Geographically, western Aldan District hosts numerous gold mining operations, an industry dating to the 1920s. Since the mid-2000's, this area has also experienced oil and gas pipeline construction. Such industrial development has posed a significant and growing threat to the well-being of Indigenous northerners (Shadrin 2014). By contrast, the eastern side of the district is difficult to access and has experienced minimal industrial encroachment. In terms of political developments, a number of legal initiatives at both the federal and republican level have altered the efficacy of TTPs to provide protection from industrial development, as well as their potential role in asserting regional power vis-à-vis the federal center. Thus, comparing these two cases offers insight into the variability of TTP formation under changing center-periphery relationships at both local-regional and regional-federal scales.

Our research draws on interviews and textual analysis of official documents, as well as a review of secondary literature. The second, 

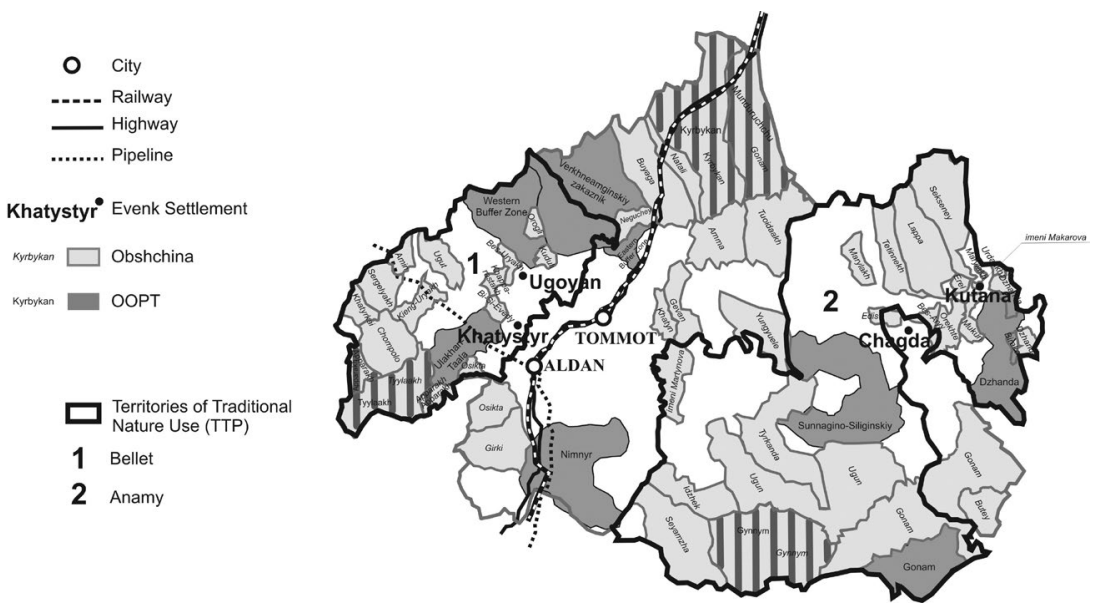

Figure 1. Map of Aldan District with Obshchinas and Naslegs

third, and fourth authors-Gail Fondahl, Viktoriya Filippova, and Antonina Savvinova, —carried out initial interviews regarding TTPs in the town of Aldan (the administrative center of the Aldan District), and in the village of Khatystyr (the administrative center of BENN), in May 2017. While in Aldan, they spoke with two individuals from ANN. The first author, Nicholas Parlato, conducted more in-depth fieldwork in June 2018, in Aldan and Khatystyr (also meeting with representatives from ANN). All authors also interviewed Indigenous leaders and policymakers in SR's capital, Iakutsk (May 2017; May-June 2018). Collectively, we conducted forty-four semistructured interviews with state and civic leaders, scholars, and community members. We also analyzed legal and other normative acts, policies, and charters related to TTPs, at the local, district, republican and federal levels and attended seminars and meetings in which TTPs were discussed.

\section{The TTP in the Sakha Republic (lakutiia): Legal Foundations and Actual Formation}

Subjects of the Russian Federation enjoy the right to enact their own legislation in areas of exclusive jurisdiction or shared jurisdiction with the federal government. These laws cannot contravene federal law but may expand on it. In 2006, SR adopted its own law on TTPs. The repub- 
lican law mostly reproduces the federal law verbatim but does add a number of important clauses. It commands signage "on the ground" that indicates the boundaries of the TTP and their "legal status and mode of use" (Article 11); it enables the establishment of areas within a TTP for protection of rare and threatened animals, water conservation and spawning grounds (Article 12.4); it requires that the procedure for removing land from a TTP involve "prior notification, consultation and with the consent of persons using the territory" (Article 15.3); and it stipulates an appeal procedure for Indigenous peoples regarding decisions made by the Republican or local governments that they feel worsen the conditions for their carrying out a traditional way of life (Article 19).

In SR, the vast majority of TTPs function as a status overlain on an extant township (nasleg) or entire district (raion/ulus). ${ }^{4}$ Doing so grants the administrations of the townships or districts the right to advance Indigenous northerners' interests locally and in relation to industry, as well as enforce a limited wildlife management protocol. SR currently has sixty-two TTPs, covering over 50 percent of its total territory (SR 2019; see also Neustroeva and Semenova 2018). Nine TTPs cover whole districts, while fifty cover naslegs (thirty-seven of these being national naslegs). ${ }^{5}$ Three local TTPs cover the territories of either a village or a single obshchina. ${ }^{6}$

In their goal of preserving the diverse ways of life of Indigenous northerners, as well as the biodiversity on which their traditional ways of life depend, the federal and SR laws stipulate general criteria for the size and boundaries, legal regime (i.e., procedural norms), permitted types of "traditional activities" of a TTP, and the process by which a TTP can be created (RF 2001a; SR 2006). Fulfilling each of these criteria entails a series of legal decisions and documents, including land surveys, economic reports, and the updating of municipal charters, requiring cooperation and coordination between the administration and various agencies.

In that Russia's subjects' laws must cohere with federal law, legislative/policy changes at the federal level directly correlate with procedural aspects of TTP establishment in SR, impacting each step of formation: community initiative, completion and submission of application materials, intergovernmental communications, meeting cadastral requirements, judicial proceedings, and formal registration. It is the changes in these pressures and conditions that we turn to, through an examination of the founding of two neighboring TTPs at distinctly different moments. 
The creation of TTPs in SR began shortly after the passage of the 2001 federal law on TTPs, with the establishment of four TTPs (all within the Olenek District) in 2003, predating SR's 2006 TTP law. Ten more were created in the first eight years after the SR law passed (Figure 2). The number of TTPs created each year began to increase in 2014, grew sharply in 2015 (by fourteen), and again in 2016 (by thirty-one). Three key legislative acts played a part in this growth: the improved protection afforded to Indigenous persons within TTPs provided by a republican law on "Ethnological Expertise" in 2010 (SR 2010); the legal removal of TTPs from OOPT status in 2013 due to a revision of federal law, and resultant change to the republican law on TTPs (SR 2015); and the potential threat a new federal law (unrelated to TTPs) posed to Indigenous land, the so-called 'Far East Hectare' law of 2016 (RF 2016). The Bellet TTP, established in 2008, predated these key legislative changes; the Anamy TTP, established in 2016, postdated all three. By examining the changes in procedures and decisions navigated between the leaders of the townships that serve as the bases for these two TTPs, SR and the federal center, we seek to characterize the evolving relationships between these scales of power. We first look at the formation of the Bellet Nasleg's TTP; then, after describing the three legislative changes noted above, we examine the formation of the Anamy Nasleg's TTP.

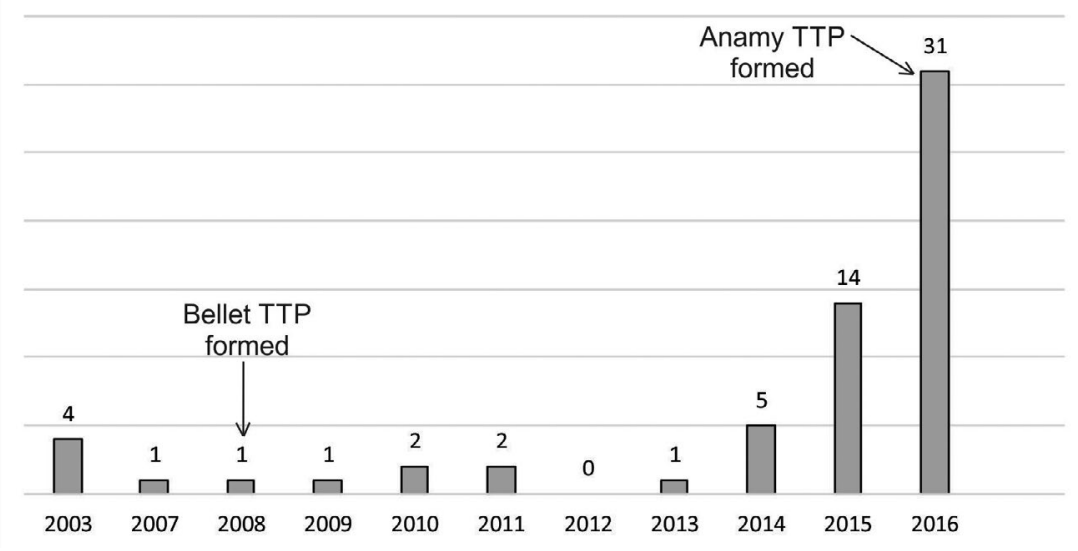

Figure 2. Number of TTPs Created in SR by Year 


\section{The Bellet TTP: A Long and Winding Road}

Early attention in the post-Soviet period to Indigenous rights (e.g., Yeltsin's 1992 Presidential Edict No. 397) encouraged Indigenous northerners to begin looking for ways of securing their ancestral territories (Fondahl and Poelzer 2003). At the turn of the millennium, with Russia's economic revival and the associated threats posed by the "second era" of industrialization (Potravniy et al. 2017), this search intensified. Local leaders' plan to formally establish the Bellet Nasleg as a "municipal formation" had been stymied since 1995 (Marfusalova 2013), but was finally resolved by a series of administrative-territorial reforms, beginning in 2004, which eliminated and consolidated small-scale settlements and redefined all "rural administrations" (sel'skie administratsii) as "municipal formations" (SR 2004a, 2004b). This reform, however, excluded "inter-settlement" areas from being included within the naslegs, leaving much of the territory commonly used for traditional activities outside the jurisdiction of the local administration. Although Bellet Nasleg had formally become an administrative-territorial organ of local self-governance, it lacked mechanisms for supporting the traditional economy as well as official records of its jurisdictional boundaries.

The Bellet Nasleg leadership subsequently voted in favor of applying for national status in 2006, resulting in an arduous legal and judicial process to transform Bellet Nasleg into an "Evenk National" nasleg, which culminated on March 24, 2008, with an affirmative decree of the SR government (SR 2008a). ${ }^{7}$ According to one interviewee, the success of this process provided the impetus to the BENN administration to also pursue TTP status and to capitalize on municipal powers granted by the law "On Local Self-Governance" (RF 2003, Art. 11) to expand the nasleg's formal boundaries. ${ }^{8}$ In June of the same year, the administration of the now legally recognized BENN immediately turned to seek TTP status for the nasleg.

After a positive referendum in 2008 ensued a two-year-long process to receive recognition for its historical territory as a TTP of local significance from the Ministry of Nature Protection. ${ }^{9}$ BENN's efforts happened to coincide with a republican project, part of the Second International Decade of Indigenous Peoples (2005-14) (RF 2014), to improve economic and legal protections for its Indigenous population. One of its key aims was the large-scale inventorying of reindeer pastures and hunting grounds (both formal territorial designations) to facilitate TTP creation, while another involved the reclassification of portions of federal land for a variety of Republican uses. The project's all-inclusive scope and 
the challenges posed by such elaborate mapping delayed BENN's particular TTP application. Three republican ministries were in charge of these activities: the Ministries of Land and Property Relations, of Agriculture, and of Nature Protection. By legislative decree in June 2009, an Interdepartmental Commission for Questions Relating to Lands within Specially Protected Nature Territories was created to facilitate the expansion of conservation areas through the complex land reforms (SR 2009a).

Under this program, in addition to the inventory of pastures and hunting grounds, survey and mapping work was carried out for 151 obshchinas across 16 districts, including Aldan. In fulfillment of the 2009 order of the SR government, "On Activities for Supporting the Economic and Social Development of Indigenous Peoples of the North of SR" (SR 2009b), the Ministry of Land and Property Relations contracted a company, Sakhagiprozem, to conduct land surveys of the obshchina territories in the Aldan, Neryungri, and Olekma districts. Once the Ministry of Nature Protection granted BENN TTP status, in late 2009, the nasleg still did not include the obshchina lands and non-settlement areas of its historical territories. The BENN administration subsequently embarked on yet another step to secure all territories within its borders. From 2009 to 2011, BENN leaders participated in monthly and quarterly meetings with the republican parliament, Il Tumen, over the legality of expanding the nasleg's territory..$^{10}$ Disputes over the legal permissibility of the TTP, spatialized beyond the settlement area and over the preexisting nasleg in its entirety proved a key challenge to its creation. To include the entire nasleg under TTP status, local leaders had to cite Article 11 of "On Local Self-Governance" (RF 2003), which recognizes "inter-settlement areas" of low population density and "areas of traditional nature use" as within the jurisdiction of the local center (in this case the village of Khatystyr) ${ }^{11}$ Its official borders were finally accepted in December 2011 (SR 2011) but would only be entered into the official Property Registry with other TTPs in 2015 through the establishment of the State Committee on National (Ethnic) Politics. ${ }^{12}$

Another spatiolegal conflict in the territory's regime, however, remains unresolved. To establish the TTP, the nasleg administration had to challenge the language of Article 30 of the federal Urban Planning Codex, which states that "the borders of territorial zones should be in concordance with the requirement that a given plot of land should belong only to one territorial zone. The formation of a single plot of land from multiple plots of land across different territorial zones is not permitted" (RF 2004). BENN's territory included four OOPTs of both local and regional significance, which had been established during former 
SR President Mikhail Nikolaev's successful inclusion of 20 percent of SR territory under protected status (Suleymanov 2017). The superimposing of a TTP spatiolegal category over the whole nasleg, including over the OOPTs, appeared to contradict the Urban Planning Code. The protection regimes of the OOPTs within the nasleg differed from that of the TTP as a whole, which was still considered a type of OOPT as well. Despite this legal inconsistency, the administration succeeded in having its request to create a TTP that included the whole of the nasleg territory approved. This resulted in a mixed protection regime for the nasleg, which was zoned accordingly, with responsibilities distributed between local and republican authorities.

Since the removal of TTPs from the federal list of OOPTs in 2013, this problem has become more politically acute, given the heightened disparity in protected statuses. According to Fedorova et al. (2015), two options have been proposed to resolve this jurisdictional collision: republican and district leaders in collaboration with the BENN administration could reduce the nasleg's territory to exclude the OOPTs or could retain the current TTP territory and "liquidate" the OOPTS. The BENN administration does not want to lose such large tracts of territory, nor does it want to forego the greater protection for the environment afforded by the OOPTs, especially in terms of wildlife.

Once conferred on the nasleg, the TTP required follow-up policy and actions to effect real changes for which the new status was hypothetically intended. Bellet Nasleg leaders spent two years negotiating and developing anti-poaching policies with district bureaus and inspectorates in the Aldan District (Parlato fieldnotes, June 2018). These leaders also strived to educate officials in the district center as well as community members on the conditions and implementation processes of the TTP. The republican Ministry for Land and Property Relations had conducted additional land surveys, fully documenting specific hunting grounds, fishing areas, and settlements, the knowledge of which facilitated both local and state understanding of the district's diverse regimes of use and protection.

We note that not all local residents could identify any significant or visible changes that the TTP provided, even after ten years of its existence. To the question of "What has the TTP provided?" several local residents of Khatystyr noted: "I'm not really sure" or "I don't know" (Fondahl, Savvinova, Filippova fieldnotes, May 2017). One community member later expanded on this: "At first, of course, on the one hand the community didn't feel anything. Every person in the village has difficulty saying exactly what changed, so there are questions. But on 
the other hand, if you look, then the status is certainly serious and does offer protection" (Parlato fieldnotes, June 2018).

\section{Key Legislative Changes Influencing TTP Creation in SR from 2010 Onward}

Between the creation of the Bellet TTP in 2008 and the Anamy TTP in 2016, three major legislative changes (one republican, two federal) greatly influenced both the rationales and processes involved in TTP creation. These changes presented challenges but also opportunities seized by republican leaders to proclaim their continued (if somewhat diminished) autonomy through the persistent creation of TTPs. Leaders of ANN, however, experienced a different path to receiving TTP status for their nasleg.

\section{SR's Ethnological Expertise Law (2010)}

The concept of "ethnological expertise," oft rendered as "cultural impact review," was mentioned in Russia's "Law on Guarantees" (RF 1999, Article 1.6). Although a law instituting ethnological expertise processes has yet to be passed at the federal level, the SR legislature (Il Tumen) adopted such a law in 2010 (SR 2010), thereby operationalizing the federal law's provision. The republican ethnological expertise law requires companies developing resources within a TTP to initiate and pay for an expert assessment of the potential cultural impacts of the proposed project. In the words of its drafter and main legal theorist in SR, Anatoly Sleptsov, the ethnological expertise serves as "an instrument of state organs, the results of which have legal consequences in the form of permission or denial of any planned land use project" $(2015,22)$. Ideally, in the minds of some Indigenous northerners who hope to protect their ancestral lands from damage, the law could potentially lead to prohibiting development; more commonly, it has led to binding obligations for companies to pay compensation for the damage that development will cause. The fact that industries are only responsible for ethnological expertise when their proposed industrial projects fall within TTPs has encouraged Indigenous groups in SR to work toward the creation of TTPs that cover their ancestral territories. While promoting Indigenous northerners' rights to protect their lands, the law has also served SR's objective to reclaim some degree of authority over the activities sanctioned for its territory. 


\section{The Loss of OOPT Status (2013)}

As noted above, legislative changes to the federal Land Codex in 2013 removed TTPs from the federal list of OOPTs (RF 2013). ${ }^{13}$ The redactions eliminated the word "nature" from the definition of a TTP (Neustroeva and Semenova 2018). As defined in SR legislation, TTPs became simply "Specially Protected Territories" (osobo okhraniaemye territorii [OOTs]) (SR 2015).

This loss of status as OOPTs signified a loss of protection for TTPs; OOTs are not required to undergo federal ecological impact review in the event of industrial development initiatives (Stammler and Ivanova 2016b). Though procedurally burdensome, status as an OOPT had secured the requirement for federal ecological impact reviews for any proposed industrial activities and allowed violations of the protection regime to be brought to the attention of federal oversight organs, such as the Federal Service for Environmental, Technological, and Nuclear Supervision (Rostekhnadzor) and the Russian State Prosecutor. As one interviewee noted, "TTPs were OOPTs, so they had super-protected status. You needed to make a lot of agreements with federal infrastructures, so the process was extremely complicated. On the one hand, the loss of that status created conditions for a simplified local process of creation. On the other hand, part of its protection regime has been lost" (Indigenous leader, Iakutsk; Parlato fieldnotes, May 2018).

Although the legal regime of nature protection that governs TTPs is no longer secured by the federal government, protection in SR remains in place by the force of the 2006 republican TTP law and the Decree “On Certifying Provisions ..." (SR 2006a, 2006b). Through changes to this decree in 2016 (SR 2016), republican legislators expanded on the declarative provisions of the federal legislation on TTPs to define the SR OOT legal regime and the creation process, while omitting some more restrictive provisions such as a prohibition on motor vehicles. However, these laws have no authority to regulate federally sanctioned actors (i.e., extractive industries with federally issued licenses), a fact that led the president of the Russian Association for Indigenous Peoples of the North to state that "the removal of the OOPT status practically makes protecting traditional ways of life impossible" (quoted in Neustroeva and Semenova 2018: 1). Vladimir Kryazkhov, a leading legal scholar on Indigenous rights in Russia, opined that "the entire gamut of negative consequences due to this change is not quite understood" (2015a: 77). Nevertheless, the silver lining of losing status as OOPTs was that TTPs 
of regional (republican) and local status now devolved fully to republican control, which in many ways facilitated their creation.

\section{The Russian Federation Law on the Far East Hectare and SR Responses (2015-2016)}

In early 2015, the Russian parliament, with the enthusiastic backing of President Vladimir Putin, began developing a program known colloquially as the Far East Hectare (FEH). Envisioned as a way to attract population to the Far East Federal District, including SR, which has lost significant population in the post-Soviet period, the FEH program permits any Russian citizen to apply for a free hectare of land in the District (Fondahl et al. 2019). The leadership of several federal subjects, including SR, was not pleased with this unilateral federal initiative. SR leaders immediately proposed several amendments to the draft law that would authorize the FEH program, including, most importantly, the exclusion of TTP lands from the FEH program. Perhaps confident that the amendment on TTP exclusion would be adopted, SR also launched an aggressive program of creating new TTPs, well prior to the passage of the FEH law in February 2016. This was facilitated by the TTPs' loss of OOPT status; TTP establishment procedures now fell under republican jurisdiction. In addition, given that many of the TTPs created earlier had not completed the expensive detailed cadastral work required to register (and achieve full legal status), to protect against the FEH the republic government supported this work for both new and extant TTPs, both logistically and financially (Fondahl et al. 2019).

By the end of 2016, SR had created fifty-nine TTPs (figure 2). While it is difficult to tease out the impact that each of the above legal changes had, they worked together to both encourage and facilitate the creation of TTPs in SR. It was within this new legal environment that ANN sought TTP status.

\section{Anamy National Nasleg's TTP: With a Little Help from My Friends}

Like Bellet Nasleg, Anamy Nasleg had become a national nasleg in 2008 (SR 2008b). ANN sought TTP status for its territory in 2016, during the year when thirty-one TTPs were established in SR (figure 2). 
The process for establishing TTPs had become significantly more streamlined than when BENN's TTP was created, thanks in large part to the creation of the Ministry for the Development of Civil Society Institutions (MinObshchestvo) and, within it, the State Committee on National (Ethnic) Politics. Moreover, redactions made in 2016 to the SR decree "On Certifying Provisions on TTPs" simplified the process to apply for TTP status (SR 2016). After these redactions were affirmed, the ANN administration held a referendum on whether to apply for TTP status. The positive outcome of this referendum was reaffirmed by the ANN Council of Deputies, which submitted the application for TTP status to MinObshchestvo. Without further debate or demands, the State Committee submitted a detailed document on ANN's proposed TTP to the republican Ministry of Property and Land Relations and the republican Ministry of Nature Protection to register the full territory in the republican cadastral database, the final essential step. The fact that ANN's territory included four OOPTs and twenty-one obshchinas, did not appear to hinder the quick progress, as had been the case with BENN.

ANN's efforts to create a TTP were conducted entirely with the paternalistic support of the SR government, as one of the dozens of TTPs facilitated during SR's political battle against the FEH program. The community's decision to create a TTP was not born from an urgent need for protection against industrial encroachment, as was the case in BENN, but from the convenience of a formation process supported by an interested republican government and because of its potential future benefits rather than current threats. In its short history as a TTP, ANN has been able to rely faithfully on the SR government to defend its protected status, enacting community control only with regards to its own residents, whereas BENN has been forced to articulate and advance its protected status against powerful nonlocal interests.

\section{Discussion}

In comparison to that of BENN, ANN's experience in establishing a TTP was significantly simpler and faster, a result of four key factors: 1) the differing geographies of the two naslegs; 2 ) the accumulation of both experience and protocols in creating TTPS; 3) the changes in protection afforded to TTPs at both the federal and republican level; and 4) the increased utility TTPs offered to assert republican authority, in an era of decreasing autonomy. 


\section{Different Geographies: Resources and Remoteness}

As of today, the TTPs of BENN and ANN are bound by the same laws. Dramatically different conditions, however, impelled the communities' decision to embark on forming a TTP and influenced the duration and complexity of the process. As the active site of industrial activity, for both the extraction and transport of natural resources and with borders limited by its initial nasleg status, BENN sought the protection and expanded jurisdiction that a TTP would provide. Although numerous gold mines have operated for decades within what is now BENN, the plan to (re)route the Eastern Siberian Pacific Ocean pipeline through BENN (formally announced in 2008, but preceded by reconnaissance) (Yakovleva 2011) made BENN's TTP formation process urgent and entangled with conversations about the land's legal status and community control over activities on the land. Seeking TTP status-at the time as an OOPT-BENN experienced an application process bound up with a republican-wide effort to remedy a problematic lack of information on its territories. Difficulties of communication between rural, semiisolated BENN, the Ministry of Nature Protection in Iakutsk, and its parent ministry in Moscow further impeded the process of gaining the mandatory permissions for the TTP. Meanwhile, BENN's geographic proximity to the headquarters of Aldanzoloto, a major gold mining company, in Nizhny Kuranakh and to the district center of Aldan did facilitate communication with key stakeholders and decision-makers, but it also meant that local community priorities competed with industrial ones at both the district and republican level (Parlato fieldnotes, June 2018). By contrast, ANN's geographic isolation and lack of economically exploitable minerals have allowed residents to live relatively free from outside disruptions (except for two small and elusive gold-mining outfits) (Fedorova and Ponomareva 2012).

\section{The Passage of Time: Experience Begets Procedures and Protocols}

During the earlier years of TTP formation, in the absence of regional (republican) bylaws, the responsible ministries and agencies of SR had no official protocol for dealing with TTP applications, especially as they involved multiple land users and land designations. Coordination between ministries was poor, and the burden of overseeing and ensuring the success of the application fell to the applicants, that is the 
local administrations (Parlato fieldnotes, June 2018). However, through the drawn-out processes undertaken by the first twelve applicants for TTPs, the procedures and legislation associated with establishing TTPs became more familiar to urban bureaucrats and specialists. Redactions made in 2016 to the 2006 Republican Decree No. 267 “On Certifying Provisions on Territories of Tradition Nature Use of the Indigenous Small-Numbered Peoples of the North of SR" (SR 2016) finally systematized the necessary steps, while the mass inventorying of territories provided the base level information for making TTP decisions.

\section{Removing Protection, Removing Obstacles}

For early TTPs, OOPT status both enhanced the level of protection available and entangled all local decisions and procedures with national requirements and political interests. When the OOPT status was removed in 2013, decision making for TTPs of regional and local significance became the exclusive purview of regional governments, which could pass bylaws establishing their own procedures. With no need to adhere to the strict requirements of the Federal Agency for Ethnic Affairs or the Ministry of Natural Resources and the Environment, SR leaders could streamline the process of TTP creation.

\section{Protecting Republican Sovereignty by Protecting Indigenous Northerners}

Reacting to federal actions that weakened protections on Indigenous northerners' land, SR's moves to provide greater protection to TTP lands in the face of industrial development (via the 2010 Ethnological Expertise law) and to facilitate and considerably increase the number of TTPs in the face of a federal land giveaway program (FEH), should be understood as a strategic retort to Moscow (Fondahl et al. 2019). Both the mass creation of TTPs and the development of the Ethnological Expertise Law serve SR's objective to reclaim some degree of authority over the activities sanctioned for its territory. Under the leadership of Vladimir Putin, Russia has undergone a mass centralization of political power (Bahry 2005; Tysiachniouk et al. 2018b). The federal government has revoked many privileges formerly enjoyed by regions, including the "Two-Key Principle," which gave regional governments veto powers over questions of economic development (Adachi 2009). In 2003 the 
federal government withdrew from the 1995 Moscow-Iakutsk bilateral agreement, which had granted the SR significant powers (Balzer 1996). But by elaborating on the special regime of Indigenous rights secured under federal law, SR legislators have been able to circumvent some of the limitations on autonomy imposed by the federal center.

As a body with legislative and delegative ${ }^{14}$ powers, the republican government has adopted a strategy for advancing Indigenous rights that simultaneously expands its own sovereignty over its territory and insulates lower tiers of governance (districts and naslegs) from potential cooptation and overreach. The ethnological expertise law accomplishes the former by acting as an albeit weak substitute form of control for the annulled "Two-Key Principle." The latter is accomplished by creating only local- and district-level TTPs, rather than republican-level, which would be subject to more regional and even federal influences (interview with an Indigenous leader in Iakutsk, May 2018). The SR leadership recognizes that the well-being of its cultural landscape, and thereby the support of its population, is its greatest asset when interacting with the federal center. Built on a distinctly generous legal approach to Indigenous rights that SR has adopted since the early 1990s (Fondahl et al. 2000), the symbiotic use-value of the relationship between local Indigenous leaders and their republican counterparts ensures close and respectful collaboration.

\section{Future Prospects}

The constant efforts of federal legislators to roll back Indigenous rights have been well-documented in the scholarly literature (Kondrashev et al. 2018; Kryazhkov 2010; Semenova 2007; Tranin 2010). It is not surprising then that backers of SR's progressive policies regarding Indigenous northerners must continue to defend them in the national arena. Recent federal legislative projects have included introducing minor terminological changes to key Indigenous and land use laws, which would result in a proliferation of loopholes and "legal collisions" advantaging non-traditional land users ("Malen'kie izmeneniia," 2018). Proposals for changes to the federal law on TTPs suggest establishing all TTPs exclusively at the federal level, which would strip control from SR and other subjects over the formation and preservation of these territories and might liquidate extant TTPs ("Elena Golomareva" 2017; "V Il Tumene" 2019). The drafting of a federal ethnological expertise law, instigating federally determined procedures (e.g., for calculating 
compensation) would potentially enfeeble SR's law, which would have to be brought into conformance with its federal variant (Pravitel'stvo 2019; "V gosdume" 2018). Each of these projects would entail a reduction in regions' ability to develop their own land use policy as well as a diminishment in the standing of Indigenous northerners in relation to both subsoil users and other national minorities. Despite the success of SR's TTP system, it may not persist in this form over time.

The evolution of TTP formation procedures detailed in this article is less an indicator of political progress as it is of the dynamism of Indigenous territorial politics and the persistent tensions between regions and the federal center. The Bellet and Anamy TTPs can both be considered sites of legal territorial experimentation, where local- and republican-level leadership used the tools available to build common cause and protect their interests against the powerful national executive. Their successes have demonstrated that bottom-up activism, bolstered by legislation and constitutional guarantees, can effectively challenge predominant legal and political orders and drive systematic reform in the advancement of Indigenous rights. Indigenous northerners' ability to continue leading a traditional lifestyle and preserve their culture depends, ultimately, on the perseverance and cooperative spirit of republican legal authorities and local leaders, and the preservation of community members' relationship with the past, their people, and the land.

\section{Acknowledgments}

We thank the many people who spent time with us, answering our questions and discussing the situation of TTPs in SR. We greatly appreciate the information provided by Dmitri D. Marfusalov, Elena K. Golomareva, and Viacheslav I. Shadrin, guidance given by Dr. Igor Krupnik and Dr. Gary Wilson on a related manuscript that served as a basis for this article, and constructive comments provided by the two anonymous reviewers. This research was supported by SSRHC grant 435-2016-0702 and NORRUS grant 257644/H30. 
Nicholas Parlato completed his MA in interdisciplinary studies at the University of Northern British Columbia. His research, under the aegis of Dr. Gail Fondahl's SSHRC grant, Indigenous Territorial Rights in the Russian Federation, focused on procedural, textual, and psychosocial aspects of Indigenous legal territorial formations in the Sakha Republic. Parlato has also worked as a research assistant at the Smithsonian National Museum of Natural History and the Woodrow Wilson Center, as an executive assistant at the American-Russian Cultural Cooperation Foundation, and as an ESL teacher in Ukraine and Russia. He began PhD studies at the University of Alaska Fairbanks in the fall of 2020. Email: njparlato@alaska.edu.

Gail Fondahl is a professor of geography at the University of Northern British Columbia, Canada. Her research focuses on the legal geographies of Indigenous territorial rights in the Russian North, on the cultural geography of reindeer herders, and on the cultural and governance dimensions of arctic sustainability. Fondahl served as president of the International Arctic Social Sciences Association (2011-2014) and Canada's representative to the International Arctic Science Committee's Social \& Human Sciences Working Group (2011-2018). She coedited the second Arctic Human Development Report (2014) and Northern Sustainabilities: Understanding and Addressing Change in the Circumpolar World (2017). Email: gail.fondahl@unbc.ca.

Viktoriya Filippova, PhD, and is a senior researcher at the History and Arctic Research Department of the Institute for Humanities Research and Indigenous Studies of the North, of the Siberian branch of the Russian Academy of Sciences, Iakutsk, Russia. Her research interests include settlement and demography of Indigenous peoples, traditional nature use, historical geography, GIS, and climate change. Email: Filippovav@mail.ru.

Antonina Savvinova is an associate professor of geography and head of the laboratory of electronic cartography systems at the North-Eastern Federal University in Iakutsk, Russia. She uses her expertise in GIS and remote sensing to research natural resources management of indigenous peoples of the North, sustainable development of the Northern territories, Indigenous knowledge, climate change, and natural systems of the Arctic. Email: sava_73@mail.ru. 


\section{Notes}

1. In this paper, we use the term indigenous northerners as shorthand for the "Indigenous numerically small peoples of the North, Siberia and the Far East of the Russian Federation."

2. Presidential edicts (ukazy) and orders (rasporiazheniia) often fill legal vacuums prior to federal law being passed. The Russian Constitution (Article 90) gives expansive powers to the president to use such acts. Once a law is adopted, the edict or directive loses force (Danilenko and Burnham 2000: 12).

3. The 2001 law was preceded by two other framework laws on indigenous rights: the 1999 Law on the Guarantee of Rights of Indigenous Peoples (RF 1999) and the 2000 Law on forming obshchinas (RF 2000) — both of which are also frequently branded as declarative (e.g., Kryazhkov 2010).

4. In some other regions of the Russian Federation, TTPs follow different formations; for instance, in the Khanty-Mansi Autonomous Okrug, they are formed along the boundaries of obshchina territories.

5. "National" naslegs and uluses are designated as such to provide the resident Indigenous nations/people(s) with additional protection to the culture, traditional lifeway, and the environment needed to support these (Wessendorf 2005: 91).

6. Obshchinas (clan communities) of numerically small peoples are legally defined as "forms of self-organization of persons, belonging to numerically small peoples and united on the basis of blood-relation (family, clan) and (or) territorial-neighboring attributes, created with the goal of defense of their ancestral territories, maintenance and development of a traditional way of life, economy, trades and culture" (RF 2000, Article 1).

7. The national status grants the administration of a municipal formation special rights to allocate resources in support of the activities of their indigenous population, who must comprise at least 30 percent of the total population. Having national status for a nasleg or district is not a prerequisite to pursuing TTP status for the whole nasleg or district. As of 2021, thirteen naslegs and five districts have national status.

8. Personal communication to authors, December 2019.

9. Ministry of Ecology, Nature Management and Forestry of the Republic of Sakha (Iakutiia).

10. Personal correspondence with authors, December 2019.

11. The biased legal interpretation of terminology relating to the place of residence and ethnic identity have afflicted the realization of indigenous northerners' rights for decades (Balzer 2016; Donahoe et al. 2008).

12. Personal communication to authors, December 2019.

13. The necessary changes were made to bring the law on TTPs into coherence with these changes to the Land Codex and "On Specially Protected Nature Territories." 
14. Delegative powers refer to the powers a governmental body has to distribute certain responsibilities for certain government functions relatively freely to other tiers of government: in this case, district and village level governments

\section{References}

Adachi, Yuko. 2009. "Subsoil law reform in Russia under the Putin administration." Europe-Asia Studies 61, no. 8: 1393-414. DOI: 10.1080/ 09668130903134814.

Bahry, Donna. 2005. "The new Federalism and the paradoxes of regional sovereignty in Russia." Comparative Politics 37, no. 2: 127-146.

Balzer, Marjorie, and Uliana Vinokurova. 1996. "Nationalism, interethnic relations, and federalism: The case of the Sakha Republic (Iakutiia)." Europe-Asia Studies 48, no. 1: 101-120.

Balzer, Marjorie. 2006. "The tension between might and rights: Siberians and energy developers in post-socialist binds." Europe-Asia Studies no. 58: 567-588. DOI: 10.1080/09668130600652142.

Balzer, Marjorie. 2016. "Indigeneity, land and activism in Siberia." In Land, indigenous people and conflict, ed. Alan Tidwell and Barry Zellen, 9-27. New York: Routledge.

Bogoslovskaya, Lyudmila. 2016. "Prava korennykh narodov Severa na zemli (territorii) kak osnovu svoego sushestvovaniia i etnicheskoi samobytnosti" [The land rights of Indigenous Peoples of the North as the foundation of their existence and ethnic identity]." In Litsom kmoriu: pamiati Liudmily Bogoslovskoi [With one's face to the sea: Memories of Liudmila Bogoslovskaia], ed. Igor Krupnik, 606-620. Moscow.

Danilenko, G. M. \& Burnham, W. (2000). Law and legal system of the Russian federation. Juris Pub Incorporated.

Elena. 2017. “Elena Golomareva: Zakonoproekt ne sootvetstvuet zakreplennym konstitutiyey Rossiyskoy Federatsii printsipam" [Elena Golomareva: The proposed bill does not accord with principles secured by the Russian constitution"]. 2017. Il Tumen Press Service. http://yakutiakmns.org/ archives/7318.

Fedorova, E. N., and G. A. Ponomareva. 2012. “Sovremennoe sostoianie rasseleniia naseleniia iuzhnoi Iakutii" [The current condition and distribution of the population of southern Iakutiia]. Strategiia Razvitiia Regiona (Strategic Regional Development) 16, no. 157: 29-36.

Fedorova, A., G. A. Gnatyuk, V. V. Filippova, A. N. Savvinova, and A. Y. Svinoboeva. 2015. “Territorii traditsionnogo prirodopol'zovaniia i OOPT iuzhnoi Iakutii: Problemy zemlepol'zovaniia na primere Belletskogo Evenkiiskogo Natsional'nogo Naslega" [Territories of traditional nature use and OOPTs 
of southern Iakutiia: Problems of land use using the example of the Bellet Evenk National Nasleg]. Paper presented at I Rossiiskaia NauchnoPrakticheskaia Konferentsiia Prirodopol'zovanie v Arktike: Sov remennoe Sostoianie i Perspektivy Razvitiia [First Russian Scientific-Practical Conference on Nature Use in the Arctic: Contemporary Conditions and Perspectives on Development], Iakutsk. 647-651.

Fondahl, Gail, O. Lazebnik, and Greg Poelzer. 2000. "Aboriginal territorial rights and the sovereignty of the Sakha Republic." Post-Soviet Geography and Economics 41, no. 6: 401-417.

Fondahl, Gail, and Greg Poelzer. 2003. "Aboriginal land rights in Russia at the beginning of the twenty-first century." Polar Record 39, no. 209: 111-122. DOI: $10.1017 /$ S0032247402002747.

Fondahl, Gail, Viktoriya Filippova, Antonina Savvinova, Aytalina Ivanova, Florian Stammler, and Gunhild Hoogensen Gjørv. 2019. "Niches of agency: Managing state-region relations through law in Russia." Space and Polity 23, no. 1: 49-66. DOI: 10.1080/13562576.2019.1594752.

Ivanova, Aytalina, and Florian Stammler. 2017. "Mnogoobrazie upravleiaemosti prirodnymi resursami v Rossiiskoi Arktike" [A diversity of ways of governing natural resources in the Russian Arctic]. Sibirskie Istoricheskie Issledovaniia no. 4: 210-225.

Kondrashev, Andrey, Olga V. Ronzhina, and Alexandra B. Zenkina. 2018. “The territory of traditional nature use as a specific territorial unit in the system of territorial division of the North, Siberia and the Russian Far East." Journal of Siberian Federal University-Humanities and Social Sciences 11, no. 10: 1572-1592. DOI: 10.17516/1997-1370-0322.

Kryazkhkov, Vladimir. 2010. Korennye malochislennye narody severa v Rossiiskom prave [Indigenous numerically small peoples of the North in Russian law]. Moscow: Norma.

Kryazhkov, Vladimir. 2013. “Development of Russian legislation on Northern Indigenous Peoples." Arctic Review on Law and Politics 4, no. 2: 140-155.

Kryazhkov, Vladimir. 2015a. "Legal regulation of the relationships between Indigenous Small-Numbered Peoples of the North and subsoil users in the Russian Federation." Northern Review no. 39: 66-87.

Kryazhkov, Vladimir. 2015b. "Zakonodatel'stvo ob obshchinakh korennykh malochislennykh narodov severa kak razvivaiushaiasia sistema" [Legislation on obshchinas of the Small-Numbered Peoples of the North as a developing system]. Gosudarstvo i pravo no. 11: 49-58.

"Malen'kie izmenenia mogut imet' bol'shie posledstviia" [Small changes can have large consequences]. 2018. Il Tumen Press Service. http://iltumen.ru/ content/ percentC2 percent $\mathrm{ABmalenkie-izmeneniya-mogut-imet-bolshie-}$ posledstviya percentC2 percentBB.

Marfusalova, Avgusta. 2013. V zhizni dolzhen byt' smysl [Life should have a purpose]. Iakutsk: Saidam. 
Marfusalova, Avgusta. 2018. Zhizn'v razvitii (Life in development). Iakutsk: Saidam.

Minchenko, N. V. 2007. "Nekotorye problemy pravovogo regulirovaniia traditsionnogo prirodopol'zovaniia korennykh malochislennykh narodov $\mathrm{v} \mathrm{RF}^{\prime}$ [Some problems on the legal regulation of traditional nature use of the Indigenous Small-Numbered Peoples of the RF]. Aktual'nye Problemy Rossiskovo Prava (Actual Problems of Russian Law) no. 1: 238-244.

Naprasnikov, A. T., L. M Koritniy, M. V. Ragulina, V. M. Parfenov, N. V. Vlasova, I. L. Savel'eva, L. L. Kalel, N. P. Olenik, G. V. Ponomarev, M. V. Romanova, and V. V. Chukmasov. 2005. Territorii traditsionnova prirodovpol'zovaniia: Geograficheskie aspekty, obosnovaniia, $i$ analiza (Territories of traditional nature use: Geographic aspects, logics, and analysis). http://www.rfbr.ru/ rffi/portal/books/o_68574\#1.

Neustroeva, A. B., and L. A. Semenova. 2018. “Osobennosti rasseleniia korennykh malochislennykh narodov Severa na territoriiakh traditsionnogo prirodopol'zovaniia Respubliki Sakha (Iakutiia)" [Particularities of the populations of Small-Numbered Indigenous Peoples of the North on territories of traditional nature use of the Republic of Sakha (Iakutiia)]. Urbanistika no. 4: 22-35. http://e-notabene.ru/pr/article_24896.html.

Potravniy, I., V. Gassiy, and S. Afanas'ev. 2017. “Territorii traditsionnovo prirodopol'zovaniia: Ogranicheniia razvitiia ili faktory ekonomicheskogo rosta?" [Territories of traditional nature use: Limiting development or a factor of economic growth?]. Arktika: Ekologiia i Ekonomika (Arctic: Ecology and Economics) 2, no. 26: 4-16.

Pravitel'stvo RF. 2019. "Pravitel'stvo RF opredelit poriadok vozmeshcheniia ubytkov Malochislennym Narodam). Il Tumen Press Service. http:// iltumen.ru/content/pravitelstvo-rf-opredelit-poryadok-vozmescheniyaubytkov-malochislennym-narodam.

RF. 1995. “Ob osobo okhraniaemykh prirodnykh territoriiakh" [On specially protected nature territories]. Law No. 33-F3, March 14, 1995.

RF. 1999. “O garantiiakh prav korennykh malochislennykh narodov Rossiiskoi Federatsii" [On guaranteeing the rights of Indigenous Small-Numbered Peoples of the Russian Federation]. Law No. 82-FZ, April 30, 1999.

RF. 2000. “Ob obshchikh printsipakh organizatsii obshchin korennykh malochislennykh narodov Severa, Sibiri, i Dal'nego Vostoka Rossiiskoi Federatsii" [On general principles for the organization of communities of Indigenous Small-Numbered Peoples of the North, Siberia, and the Far East of the Russian Federation]. Law No.104-FZ, July 20, 2000.

RF. 2001a. “O territoriiakh traditsionnogo prirodopol'zovaniia korennykh malochislennykh narodov Severa, Sibiri, i Dal'nego Vostoka Rossiiskoi Federatsii" [On territories of traditional nature use of the Indigenous Small-Numbered Peoples of the North, Siberia, and the Far East of the Russian Federation] Law No.49-FZ, May 7, 2001. 
RF. 2001b. "Zemel'nyi kodeks Rossiiskoi Federatsii" [Land codex of the Russian Federation]. Law No. 136-FZ, October 25, 2001.

RF. 2003. “Ob obshchikh printsipakh organizatsii mestnogo samoupravleniia Rossiiskoi Federatsii" [On general principles of the organization of local self-government in the Russian Federation]. Law No. 131-F3, October 6, 2003.

RF. 2004. "Gradostroitel'skiy kodeks Rossiyskoy federatsii" [Urban Planning Code of the Russian Federation], No.190-FZ, December 29, 2004.

RF. 2013. “O vnesenii izmenenii v Federal'nyi Zakon 'Ob Osobo Okhraniaemykh Prirodnykh Territoriiakh' i otdel'nye zakonodatel'nye akty Rossiiskoi Federatsii [On implementing changes in the Federal Law 'On Specially Protected Nature Territories' and other legal acts of the Russian Federation]. Law No. 406-F3, December 28, 2013.

RF. 2014. “Otchet o khode realizatsii kompleksnogo plana Meropriiatii Respubliki Sakha (Iakutiia) po provedeniiu vtorogo mezhdunarodnogo desiatiletiia korennykh narodov mira za period 2008-2014" [Report on the progress of realizing the complex plan of activities of the Sakha Republic (Iakutiia) in fulfilling the second international decade of indigenous peoples of the world for 2008-2014].

RF. 2016. “Ob osobennostiakh predostavleniia grazhdanam zemel'nykh uchastkov, nakhodiashchikhsia v gosudarstvennoi ili munitsipal'noi sobstvennosti i raspolozhennykh na territoriiakh sub"ektov Rossiiskoi Federatsii, vkhodiashchikh v sostav Dal'nevostochnogo federal'nogo okruga, i o vnesenii izmenenii v otdel'nye zakonodatel'nye akty Rossiiskoi Federatsii" [On the specifics of granting to citizens land plots in state or municipal ownership, located in the territories of the constituent entities of the Russian Federation within the Far East Federal District, and on the introduction of changes to individual legal acts of the Russian Federation'. Law No. 199-F3, May 1, 2016.

Semenova, Tamara. 2007. "Political mobilisation of Northern Indigenous Peoples in Russia." Polar Record 33, no. 1: 23-32. DOI:10.1017/S0032247406005808.

Shadrin, Vyacheslav. 2014. "How are indigenous peoples and communities in northern Iakutiia affected by industrial development?" In Sustainable development in the Circumpolar North-From Tana, Norway to Oktemtsy, Iakutia, Russia, ed. Tor Gjertsen and Greg Halseth, 201-215. Tromso: UiT. DOI: http://dx.doi.org/10.7557/5.3214.

Sirina, Anna. 2010. "Oil and gas development in Russia and Northern Indigenous Peoples." In Russia and the North, ed. Elena Wilson-Rowe, 187-202. Ottawa: University of Ottawa Press.

Sleptsov, Anatoly. 2015. “Gosudarstvennaia etnologicheskaia ekspertiza Respubliki Sakha (Iakutiia)" [The state ethnologic examination in the Republic of Sakha (Iakutiia)]. Arktika. XXI vek. Gumanitarnye Nauki [Arctic. 21st century. Human sciences] 1, no. 4: 15-24.

SR. 2004a. “Ob ustanovlenii granits i o nadelenii statusom gorodskogo i sel'skogo poselenii munitsipal'nykh obrazovanii Respubliki Sakha 
(Iakutiia)" [On establishing boundaries and endowing municipal formations with the status of urban and rural settlements in the Republic of Sakha (Iakutiia)]. Law No. 173-3 N 353-11, November 30, 2004.

SR. 2004b. "O vnesenii izmenenii i dopolnenii v zakon Respubliki Sakha (Iakutiia) ‘ Ob administrativno-territorial'nom ustroistve Respubliki Sakha (Iakutiia)'"' [On changes and additions to the Republic of Sakha (Iakutiia) law 'On the administrative-territorial structure of the Republic of Sakha (Iakutiia)']. Law No. 196-3 N 395-III, December 29, 2004.

SR. 2006a. “O territoriiakh traditsionnogo prirodopol'zovaniia i traditsionnoi khoziaistvennoi deiatel'nosti korennykh malochislennykh narodov severa Respubliki Sakha (Iakutiia)" [On territories of traditional nature use and traditional land use of the Indigenous Small-Numbered Peoples of the North of the Sakha Republic (Iakutiia]. Law No. 370-3 N 755-III, July 13, 2006.

SR. 2006b. "Ob utverzhdenii polozheniia o territoriiakh traditsionnogo prirodopol'zovaniia korennykh malochislennykh narodov severa Respubliki Sakha (Iakutiia)" [On affirming provisions on territories of traditional nature use of Indigenous Small-Numbered Peoples of the North of the Sakha Republic (Iakutiia)]. Law No. 267, June 22, 2006.

SR. 2008a. “O nadelenii Belletskovo Nasleg (sel'skogo okruga) Aldanskogo Ulusa (raiona) Respubliki Sakha (Iakutiia) statusom 'Evenkiiskii Natsional'nyi'"' [On endowing the Bellet Nasleg (rural okrug) in the Aldan Ulus of the SR with the status of "National Evenk"]. Decree of the Government of SR No. 121, March 24, 2008.

SR. 2008b. “O nadelenii Anaminskogo Naslega (sel'skogo okruga) Aldanskogo Ulusa (raiona) Respubliki Sakha (Iakutiia) statusom 'Natsional'nii'” (On endowing the Anamy Nasleg (rural okrug) in the Aldan Ulus of the SR with the status of "National"). Decree of the Government of SR No. 117-IV, June 19, 2008.

SR. 2009a. "O sozdanii mezhvedomstvennoi komissii po zemel'nym voprosam osobo okhraniaemykh prirodnykh territorii Respubliki Sakha (Iakutiia)" [On the creation of the interdepartmental commission on questions relating to lands of specially protected nature territories of the SR]. Law No. 647-p, July 14, 2009.

SR. 2009b. “O meropriiatiiakh po podderzhke ekonomicheskogo i sotsial'nogo razvitiia korennykh malochislennykh narodov severa Respubliki Sakha (Iakutiia)" [On activities for supporting the economic and social development of Indigenous Numerically-Small Peoples of the North of SR]. Law No. 1088-p, November 11, 2009.

SR. 2010. “Ob etnologicheskoyekspertize v mestakhtraditsionnogoprozhvaniya I traditsionnoy khozyaystvennoy deyatel'nosti korennykh malochislennykh narodov Severa Respubliki Sakha (Iakutia)" [On ethological expertise in places of traditional habitation and traditional economic activities of Indigenous Numerically-Small Peoples of the North of Sakha Republic (Iakutia)], Law N. 820-3 N 537-IV, April 14, 2010. 
SR. 2011. “O vnesenii izmenenii v zakon Respubliki Sakha (Iakutiia) ‘Ob ustanovlenii granits i o nadelenii statusom gorodskogo i sel'skogo poselenii munitsipal'nykh obrazovanii Respubliki Sakha (Iakutiia)'” [On changes to the SR law "On establishing the boundaries and endowing municipal formations with the status of urban and rural settlement"]. Law No. 1014-3 N 905-IV, December 15, 2011.

SR. 2015. “O vnesenii izmenenii v zakon Respubliki Sakha (Iakutiia) ‘O territoriiakh traditsionnogo prirodopol'zovaniia i traditsionnoi khoziaistvennoi deiatel'nosti korennykh malochislennykh narodov severa Respubliki Sakha (Iakutiia)" [On changes to the Republic of Sakha (Iakutiia) law "On territories of traditional nature use and traditional land use activities of the Indigenous Small-Numbered Peoples of the North of the Republic of Sakha (Iakutiia)." Law No. 1456-3 N 467-V, May 28, 2015.

SR. 2016. “O vnesenii izmenenii v postanovlenie pravitel'stva Respubliki Sakha (Iakutiia) ot 22 Iunia 2006 No. 267 'Ob utverzhdenii polozheniia o territoriiakh traditsionnogo prirodopol'zovaniia korennykh malochislennykh narodov severa Respubliki Sakha (Iakutiia)" [On changes to the decree of the government of the Republic of Sakha (Iakutiia) from June 22, 2006, No. 267 , “On certifying provisions on territories of traditional nature use of the Indigenous Small-Numbered Peoples of the North of the Republic of Sakha (Iakutiia)]. Law No. 222, July 1, 2016.

SR. 2019. “Vypiska iz reestra TTP po sost. na 06.09.2019” [Excerpt from registry of TTPs as of June 9, 2019]. https://arktika.sakha.gov.ru/dejatelnost1—/ TTP.

Stammler, Florian, and Aytalina Ivanova. 2016a. “Confrontation, coexistence or co-ignorance? Negotiating human-resource relations in two Russian regions." Extractive Industries and Society 3, no. 1: 60-72. http://dx.doi.org/ 10.1016/j.exis.2015.12.003 2214-790X/ã.

Stammler, Florian, and Aytalina Ivanova. 2016b. "Resources, rights, and communities: Extractive mega-projects and local people in the Russian Arctic." Europe-Asia Studies 68, no. 7: 1220-1244. DOI: http://dx.doi.org/10.1080/ 09668136.2016.1222605.

Suleymanov, A. A. 2017. "Mezhdunarodnye ekologicheskie initsiativy v Arkticheskikh raionakh Iakutii v kontse dvadsatogo veka" [International ecological initiatives in the Arctic regions of Iakutiia at the end of the 20th century]. Gumanitarnyye issledovaniya $v$ Vostochnoy Sibiri i na Dal'nem Vostoke 39, no. 1, 80-90.

Tranin, A. A. 2010. Territorii traditsionnogo prirodopol'zovaniia korennykh malochislennykh narodov Rossiiskogo Severa (problemy i perspektivy) [Territories of traditional nature use of the Indigenous Small-Numbered Peoples of the Russian North (problems and perspectives)]. Moscow: Institute of Government and Law. 
Tysiachniouk, Maria, Laura A. Henry, Machiel Lamers, and Jan P. M. van Tatenhove. 2018a. "Oil and indigenous people in sub-Arctic Russia: Rethinking equity and governance in benefit sharing agreements." Energy Research $\mathcal{E}$ Social Science no. 37: 140-152. DOI: 10.1016/j.erss.2017.09.004.

Tysiachniouk, Maria, Laura A. Henry, Machiel Lamers, and Jan P. M. van Tatenhove. 2018b. "Oil extraction and benefit sharing in an illiberal context: The Nenets and Komi-Izhemtsi Indigenous Peoples in the Russian Arctic." Society \& Natural Resources 31, no. 5: 556-579.

“V Il Tumene obsuzhdeny voprosy obrazovaniia, okhrany i ispol'zovaniia territorii traditsionnogo prirodopol'zovaniia korennykh malochislennykh narodov severa" [Questions of the formation, protection, and use of TTPs of Indigenous Small-Numbered Peoples of the North were discussed in Il Tumen]. 2019. Il Tumen Press Service. http://iltumen.ru/ content/v-il-tumene-obsuzhdeny-voprosy-obrazovaniya-okhrany-iispolzovaniya-territoriy.

V Gosdume. 2018. “V Gosdume prizvali uskorit' vnesenie zakonoproekta ob etnologicheskoi ekspertize" [In the Federal Duma, calls to speed up the bill on ethnological impact review]. 2018. Parlamentskaia gazeta (Parliament news). https://www.pnp.ru/politics/v-gosdume-prizvali-uskorit-vneseniezakonoproekta-ob-etnologicheskoy-ekspertize.html

Wessendorf, K., ed. 2005. An Indigenous parliament? Realities and perspectives in Russia and the circumpolar north. Copenhagen: IWGIA.

Yakovleva, N. 2011. Oil pipeline construction in Eastern Siberia: Implications for indigenous people. Geoforum 42, no. 6, 708-719.

Zadorin, Maxim, Olga Klisheva, Ksenia Vezhlivtseva, and Daria Antufieva. 2017. Russian laws on indigenous issues. Guarantees, communities, territories of traditional land use. Rovaniemi: University of Lapland. 